\title{
ANALISIS YURIDIS PERCERAIAN DI LUAR PENGADILAN MENURUT UNDANG-UNDANG NOMOR 1 TAHUN 1974 TENTANG PERKAWINAN DAN MENURUT PENDAPAT AHLI FIKIH ISLAM
}

\author{
JURIDICAL ANALYSIS OF DIVORCE OUTSIDE THE COURT \\ ACCORDING TO LAW NUMBER 1 OF 1974 ABOUT MARRIAGE AND \\ ACCORDING TO ISLAMIC JURISPRUDENCE OPINION
}

\author{
Yulisa Fitri $^{1}$, Jamaluddin ${ }^{2}$, Faisal ${ }^{3}$ \\ ${ }^{1}$ Mahasiswa Program Studi Magister Hukum Universitas Malikussaleh \\ ${ }^{2,3}$ Dosen Program Magister Ilmu Hukum Universitas Malikussaleh \\ Email: yulisafitri028@gmail.com
}

\begin{abstract}
Divorce outside the court is still common today. This is due to the opinion of figh experts who allow divorce outside the court. The opinion of fiqh experts is considered in accordance with the provisions of Islamic law so that the Muslim community follows this provision. Contrary to the provisions of Law No. 1 of 1974 concerning Marriage which requires a divorce to be carried out before a court. The focus of attention in this research is about the legal consequences of divorce outside the court according to Law No. 1 of 1974 concerning Marriage and in the opinion of Islamic Jurisprudence experts, and the role of the state in the process of law enforcement. Based on research that has been done, according to Law No. 1 of 1974 concerning marriages, due to divorce outside the court is not legally valid. A legal and recognized divorce is a divorce that is carried out before a court of law. Meanwhile, in the opinion of Islamic Jurisprudence experts, divorce outside the court remains legally religious. Law enforcement in providing sanctions cannot be applied, because until now there has not been a single regulation that states that divorce outside the court is a crime that can be punished. In addition, Indonesia recognizes that Islamic law is a law that lives in society, so in making a new rule of law, the state needs to consider the values of the law that lives in society so that the law can be universally accepted by society. In the future, the state might be able to make a Perda or Qanun as a new regulation that contains strict sanctions for perpetrators of divorce outside the court. This is nothing but to guarantee the creation of justice and legal certainty.
\end{abstract}

Keywords: Divorce, out of court, act, Islamic jurisprudence

\section{Intisari}

Perceraian di luar pengadilan masih sering terjadi hingga saat ini. Hal ini dikarenakan adanya pendapat ahli fikih yang membolehkan terjadinya perceraian di luar pengadilan. Pendapat ahli fikih dianggap sesuai dengan ketentuan hukum Islam sehingga kemudian masyarakat Muslim mengikuti ketentuan ini. Bertolak belakang dengan ketentuan Undang-Undang Nomor 1 Tahun 1974 Tentang Perkawinan yang menghendaki sebuah perceraian di lakukan di depan pengadilan. Adapun yang menjadi fokus perhatian dalam penelitian ini ialah 
tentang akibat hukum dari perceraian di luar pengadilan menurut Undang-Undang Nomor 1 Tahun 1974 Tentang Perkawinan dan menurut pendapat ahli fikih Islam, serta peran negara dalam proses penegakan hukum. Berdasarkan penelitian yang telah dilakukan, maka menurut Undang-Undang Nomor 1 Tahun 1974 Tentang perkawinan, akibat perceraian di luar pengadilan adalah tidak sah secara hukum. Perceraian yang sah dan diakui oleh hukum adalah perceraian yang dilakukan di depan pengadilan. Sedangkan menurut pendapat ahli fikih Islam, perceraian di luar pengadilan tetap sah secara agama. Penegakan hukum dalam pemberian sanksi belum bisa diterapkan, sebab hingga kini belum ada satu aturanpun yang menyatakan bahwa perceraian di luar pengadilan merupakan sebuah kejahatan yang dapat dihukum. Selain itu Indonesia mengakui bahwa hukum Islam sebagai hukum yang hidup dalam masyarakat, sehingga dalam membuat sebuah aturan hukum baru, negara perlu mempertimbangkan nilai-nilai hukum yang hidup di masyarakat agar hukum itu dapat diterima oleh masyarakat secara universal. Kedepan negara kiranya dapat membuat sebuah Perda atau Qanun sebagai sebuah regulasi baru yang berisi tentang sanksi tegas bagi pelaku perceraian di luar pengadilan. Hal ini tidak lain untuk menjamin terciptanya keadilan dan kepastian hukum.

Kata Kunci: Perceraian, di luar pengadilan, undang-undang, fikih Islam

\section{A. Latar Belakang Masalah}

Manusia sebagai makhluk sosial tidak bisa hidup sendiri. Oleh karena itu setiap manusia perlu hidup bermasyarakat. Kelompok terkecil dari masyarakat adalah keluarga. Untuk membentuk sebuah keluarga, manusia mewujudkannya dengan melakukan sebuah pernikahan. Seorang laki-laki dan perempuan yang memutuskan untuk menikah tentulah berdasarkan cinta kasih antara satu sama lain, dan mereka telah saling berjanji untuk hidup bersama dalam ikatan pernikahan dengan rukun dan bahagia sampai maut memisahkan. Janji suci pernikahan tidak hanya antara suami, istri, dan masing-masing keluarga pasangan, namun yang paling sakral yaitu janji kepada Allah Swt. Perkawinan bukan hanya mempersatukan laki-laki dan perempuan saja, melainkan mengikatkan tali perjanjian yang suci atas nama Allah, bahwa kedua mempelai berniat membangun rumah tangga yang sakinah, tentram, dan dipenuhi oleh rasa cinta dan kasih sayang. ${ }^{1}$

Setiap orang menghendaki agar perkawinan yang dilaksanakannya itu tetap utuh sepanjang kehidupannya. Akan tetapi tidak sedikit perkawinan yang dibina dengan susah payah itu berakhir dengan suatu perceraian. Tidak selalu perkawinan yang dilaksanakan itu sesuai dengan cita-cita, walaupun sudah diusahakan semaksimal mungkin dengan membinanya secara baik, tetapi pada akhirnya terpaksa mereka harus berpisah dan memilih untuk membubarkan perkawinannya $^{2}$

Pada dasarnya perkawinan itu dilakukan untuk waktu selamanya sampai matinya salah seorang suami istri. Inilah sebenarnya yang dikehendaki agama

\footnotetext{
${ }^{1}$ Beni Ahmad Saebani, Fiqh Munakahat 1, (Bandung:Pustaka Setia, 2001), hlm.18

${ }^{2}$ Abdul Manan, Penerapan Hukum Acara Perdata di Lingkungan Peradilan Agama, (Jakarta: Kencana Prenada Media Group, 2005), hlm. 443
} 
Islam. Namun dalam keadaan tertentu terdapat hal-hal yang menghendaki putusnya perkawinan itu dalam arti bila hubungan perkawinan tetap dilanjutkan, maka kemudaratan akan terjadi. Dalam hal ini agama Islam membenarkan putusnya perkawinan sebagai langkah terakhir dari usaha melanjutkan rumah tangga. Putusnya perkawinan dengan begitu adalah suatu jalan keluar yang baik. ${ }^{3}$

Perselisihan terus menerus antara suami istri mengharuskan mereka mengambil keputusan untuk perkawinannya. Selain itu hidup dalam rumah tangga yang penuh perselisihan dan ketidakharmonisan akan berimbas tidak baik bagi kedua belah pihak terutama bagi anak-anak mereka. Pada akhirnya perceraian dianggap solusi terbaik untuk menghindari keadaan yang akan bertambah buruk. Perceraian bisa terjadi karena beberapa faktor, salah satunya adalah karena percekcokan terus menerus antara kedua belah pihak. Sedangkan baik suami atau istri tidak ada yang mau mengalah. ${ }^{4}$

Pada keadaan yang sangat mendesak, maka sebuah perceraian dibolehkan. Sebab jika perkawinan diteruskan mungkin bisa menambah kesengsaraan bagi suami istri. Selain itu jika kebersamaan suami istri dipaksakan, sementara perselisihan keduanya tidak kunjung reda, bahkan perselisihan sampai mengancam keselamatan jiwa, maka perceraian dianjurkan untuk dilakukan. Sebab jika perkawinan dipaksakan, akan menyebabkan hubungan yang tidak sehat dalam rumah tangga.

Perceraian itu diibaratkan seperti pembedahan yang menyakitkan, manusia yang sehat akalnya harus menahan sakit akibat lukanya. Jika perselisihan antara suami istri tidak juga reda, dan jalan rujuk (berdamai kembali) tidak dapat ditempuh, maka perceraian adalah jalan yang menyakitkan yang harus dijalani. Itulah alasan mengapa jika tidak dapat rujuk lagi, maka perceraian yang diambil. ${ }^{5}$ Islam memberikan kebebasan sepenuhnya kepada kedua belah pihak untuk mempertimbangkan segala sesuatunya dengan matang dalam batas-batas yang dapat dipertanggungjawabkan. Oleh karena banyaknya akibat buruk dari suatu perceraian yang menyangkut kehidupan kedua belah pihak, terutama yang menyangkut anak-anak. Dapat pula dibayangkan betapa tersiksanya seseorang, terutama pihak perempuan yang tidak merasa tenteram dalam rumah tangganya, tetapi jalan perceraian tidak dibuka. Oleh karena itu perceraian dalam situasi dan kondisi tertentu sangat diperlukan untuk menghentikan penderitaan batin. ${ }^{6}$

Meskipun perceraian dibolehkan dalam keadaan tertentu, akan tetapi perceraian harus dilakukan dengan cara dan alasan yang telah diatur dalam peraturan perundang-undangan yang berlaku di Indonesia. Hal ini sesuai dengan prinsip undang-undang perkawinan yang mepersulit terjadinya perceraian. Hal ini bukan tanpa alasan, sebab fenomena yang terjadi saat ini ialah banyak masyarakat yang melakukan perceraian sekehendak hati saja, tanpa memperhatikan tata cara perceraian itu sendiri. Misalnya suami yang terlibat percekcokan dengan istrinya hlm.190.

${ }^{3}$ Amir Syarifuddin. Hukum Perkawinan Islam di Indonesia, (Jakarta: Prenada Media, 2007),

${ }^{4}$ Satria Efendi, Problematika Hukum Keluarga Islam Kontemporer, (Jakarta: Kencana, 2004), hlm. 50

${ }^{5}$ Yusuf Qardhawi, Fiqih Wanita, (Surabaya: Penerbit Jabal, 2006), hlm 82.

${ }^{6}$ Beni Ahmad Saebeni, Fiqih Munakahat 2 (Bandung: Pusataka Setia, 2001), hlm.57 
sering menceraikan istrinya secara semena-mena. Akibat dari tindakannya itu, sebuah perceraian (talak) dianggap telah jatuh.

Indonesia telah mengatur tentang perceraian di dalam Undang-Undang Nomor 1 Tahun 1974 Tentang Perkawinan. Khusus untuk umat Islam, maka aturan perceraian telah diatur dalam Kompilasi Hukum Islam (KHI). Aturan perundang-undangan di Indonesia menyebutkan alasan putusnya perkawinan, salah satunya karena perceraian. Sebagaimana yang di atur dalam Pasal 38 Undang-Undang Nomor 1 Tahun 1974 Tentang Perkawinan yang berbunyi:"perkawinan dapat putus karena kematian, perceraian, dan atas keputusan pengadilan". ${ }^{7}$ Hal senada juga di atur dalam Kompilasi Hukum Islam (KHI), yakni pada Pasal 113 disebutkan: "perkawinan dapat putus karena kematian, perceraian dan atas putusan Pengadilan. ${ }^{8}$

Menurut ajaran Islam, perceraian diakui atas dasar ketetapan hati setelah mempertimbangkan secara matang, serta dengan alasan-alasan yang bersifat darurat atau sangat mendesak. Secara normatif Rasulullah memperingatkan bahwa Allah swt sangat membenci perbuatan itu meskipun halal untuk dilakukan. Dengan demikian, secara tersirat Rasulullah mengajarkan agar keluarga muslim sedapat mungkin menghindari perceraian. ${ }^{9}$

Di dalam sebuah hadis Nabi SAW disebutkan bahwa perbuatan yang halal namun dibenci Allah adalah perceraian. Hal ini mengisyaratkan bahwa agama Islam, pada dasarnya juga mempersulit terjadinya perceraian. Oleh karenanya sebelum melakukan perceraian, harus diupayakan terlebih dahulu jalan damai demiuntuk menghindari terjadinya perceraian tersebut.

Hukum positif Indonesia, yaitu Undang-Undang Nomor 1 Tahun 1974 Tentang Perkawinan, yang didalamnya mengatur masalah perceraian, misalnya tata cara perceraian, alasan sebuah perceraian, serta sahnya perceraian menurt hukum. Sedangkan bagi pemeluk yang beragama Islam, tunduk pada ketentuan Kompilasi Hukum Islam (KHI).

Adapun Undang-undang perkawinan telah mengatur tentang syarat sahnya suatu perceraian. Menurut Pasal 39 ayat (1) Undang-Undang Nomor 1 Tahun 1974 Tentang Perkawinan bahwa: "Perceraian hanya dapat dilakukan di depan sidang pengadilan setelah pengadilan yang bersangkutan berusaha dan tidak berhasil mendamaikan". ${ }^{10}$

Sedangkan pada Kompilasi Hukum Islam (KHI) syarat sah perceraian sebagaimana diatur dalam Pasal 115 yang berbunyi: "Perceraian hanya dapat dilakukan di depan sidang Pengadilan Agama, setelah Pengadilan Agama tersebut berusaha dan tidak berhasil mendamaikan kedua belah pihak. "11

Undang-undang perkawinan dan Kompilasi Hukum Islam menyatakan bahwa perceraian tidak boleh dilakukan secara sesuka hati kedua pihak, baik suami maupun istri. Hal ini sebagaimana bunyi Pasal 39 ayat (2) UU perkawinan bahwa: "Untuk melakukan perceraian harus ada cukup alasan bahwa antara

\footnotetext{
${ }^{7}$ Indonesia, Undang-Undang Perkawinan, UU Nomor 1 Tahun 1974, Ps 38

${ }^{8}$ Instruksi Presiden Nomor 1 Tahun 1991 Kompilasi Hukum Islam, Ps.113

${ }^{9}$ Satria Efendi, op cit., hlm.48

${ }^{10}$ Indonesia, Undang-Undang Perkawinan, UU Nomor 1 Tahun 1974, Ps. 39 ayat (1)

${ }^{11}$ Instruksi Presiden Nomor 1 Tahun 1991 Tentang Kompilasi Hukum Islam Ps.115
} 
suami istri itu tidak akan dapat rukun sebagai suami isteri". ${ }^{12}$ Alasan perceraian secara lebih rinci diatur di dalam Pasal 18 Peraturan Pemerintah No. 9 Tahun 1975 Tentang Pelaksanaan Undang-Undang Nomor 1 Tahun 1974 Tentang Perkawinan dan Pasal 116 Kompilasi Hukum Islam, yaitu:

a. Salah satu pihak berbuat zina, atau menjadi pemabuk, pemadat, penjudi dan lain sebagainya yang sukar disembuhkan;

b. Salah satu pihak mendapat hukuman penjara 5 (lima) tahun atau hukuman yang lebih berat setelah perkawinan berlangsung;

c. Salah satu pihak melakukan kekejaman atau penganiayaan berat yang membahayakan pihak lain;

d. Salah satu pihak mendapat cacat badan atau penyakit dengan akibat tidak dapat menjalankan kewajibannya sebagai suami atau istri;

e. Antara suami dan istri terus menerus terjadi perselisihan dan pertengkaran dan tidak ada harapan akan hidup rukun lagi dalam rumah tangga;

f. Suami melanggar taklik talak;

g. Peralihan agama atau murtad yang menyebabkan terjadinya ketidakrukunan dalam rumah tangga.

Beberapa ahli fikih berpendapat berbeda soal perceraian. Menurut mereka perceraian tidak harus dilakukan di pengadilan. Kenyataan inilah yang hari ini masih terjadi. Akibat hal ini, pihak istri sering dirugikan dengan sikap pihak suami yang terkesan santai dan seenaknya dalam menjatuhkan cerai terhadap mereka. Ini kemudian seolah menjadi pembiaran atau pembenaran, karena muncul anggapan bahwa pendapat ahli fikih ialah pendapat yang sesuai dengan ajaran Islam, sehingga tidak ada yang salah dengan tindakan tersebut.

Oleh karena adanya pendapat ahli fikih tersebut, perceraian luar pengadilan menjadi hal yang biasa dan lumrah dilakukan. Ketika suami mulai tidak suka dengan istrinya, ia akan mulai mencari-cari alasan demi untuk bisa bercerai. Hal ini dilakukan karena perceraian dianggap gampang untuk dilakukan. Sebab tidak ada ganjaran atau hukuman apapun yang bisa dilakukan kepada suami. Hal ini dikarenakan tidak ada aturan bagi pelaku perceraian di luar pengadilan untuk dihukum. Istri pada akhirnya tidak bisa melakukan apa-apa, kecuali pasrah dengan keadaan.

Bagi sebagian umat Islam Indonesia, aturan mengenai perceraian ini merupakan ganjalan yang relatif masih besar atau sekurang-kurangnya masih menjadi tanda tanya yang belum terjawab, karena dirasakan tidak sejalan dengan kesadaran hukum yang selama ini berkembang, yaitu aturan fikih klasik. Aturan fikih mengizinkan perceraian atas dasar kerelaan kedua belah pihak, atau atas inisiatif suami atau juga inisiatif istri secara sepihak, bahkan perceraian boleh dilakukan tanpa campur tangan lembaga peradilan. Aturan perceraian yang tertera dalam undang-undang perkawinan ini serta aturan pelaksanaan lainnya dirasakan

${ }^{12}$ Indonesia,Undang-Undang Nomor 1 Tahun 1974 Tentang Perkawinan,Ps. 39 ayat (2), 
terlalu jauh perbedaannya dengan kesadaran hukum yang ada ditengah masyarakat Muslim sehingga menimbulkan kesulitan di lapangan. ${ }^{13}$

Masalah yang kemudian timbul adalah bagaimana sebenarnya hal perceraian diatur menurut hukum positif dalam hal ini Undang-Undang Nomor 1 Tahun 1974 Tentang Perkawinan, dan bagaimana jika dibandingkan dengan konsep perceraian menurut pendapat ahli fikih. Kemudian apakah negara dapat melakukan penjatuhan sanksi dengan sebuah peraturan dalam rangka proses penegakan hukum terkait kasus perceraian di luar pengadilan. Hal ini mengingat Indonesia selain berlaku hukum positif juga dapat diterapkan hukum Islam pada daerah tertentu dan terhadap kasus-kasus tertentu. Tujuannya adalah tidak lain untuk meminilisir kasus perceraian di luar pengadilan, sehingga tujuan hukum dalam sebuah negara akan tercapai. Berdasarkan latar belakang yang telah diuraikan diatas, maka yang menjadi rumusan masalah yaitu bagaimanakah konsep dan akibat hukum perceraian di luar pengadilan menurut Undang-Undang Nomor 1 Tahun 1974 tentang Perkawinan dan menurut pendapat ahli fikih dan bagaimanakah bentuk penegakan hukum dengan pemberian sanksi dapat dilakukan oleh negara.

\section{B. Metode Penelitian}

Penelitian yang akan dilakukan adalah penelitian normatif, sebab penelitian ini mengkaji peraturan perundang-undangan dan melakukan perbandingan antara satu peraturan dengan peratuan yang lain. Penelitian normatif adalah penelitian hukum yang meletakkan hukum sebagai sistem norma. Sistem norma yang dimaksud adalah mengenai asas-asas, norma, kaidah dari peraturan perundang-undangan, putusan pengadilan, perjanjian serta doktrin (ajaran). ${ }^{14}$

Penelitian ini bersifat deskriptif, dimana penulis menggambarkan fenomena atau keadaan yang terjadi di masyarakat terkait kasus perceraian di luar pengadilan. Penelitian deskriptif yakni penelitian yang berusaha untuk menuturkan pemecahan masalah yang ada sekarang berdasarkan data, menyajikan data serta menganalisis dan menginterprestasi. ${ }^{15}$ Adapun sumber utama dalam penelitian normatif adalah data sekunder. Data sekunder merupakan data yang diperoleh dari bahan kepustakaan atau literatur yang mempunyai hubungannya dengan objek penelitian. ${ }^{16}$

Bahan hukum yang dikaji dan dianalisis dalam penelitian ini terdiri dari: bahan hukum primer yang meliputi Undang-Undang Perkawinan, Kompilasi Hukum Islam, dan peraturan perundang-undangan lainnya yang berkaitan dengan judul ini. Bahan hukum sekunder diperoleh dari buku-buku, rancangan undangundang, hasil penelitian ahli hukum, dan lain-lain. Bahan hukum tertier diperoleh dari Kamus Hukum, Kamus Besar Bahasa Indonesia, Ensiklopedia, dan lain-lain.

\footnotetext{
${ }^{13} \mathrm{Al}$ Yasa Abu Bakar, sebagaimana dikutip oleh HM. Anshary, Hukum Perkawinan di Indonesia,(Yogyakarta : Pustaka Pelajar, 2010), hlm.82

${ }^{14}$ Salim Lubis HS dan Erlies Septiana Nurbaini, Penerapan Teori Hukum Pada

Penelitian Tesis Dan Disertasi, (Jakarta: Raja Grafindo Persada, 2014), hlm.13 2013), hlm.44

${ }^{15}$ Cholid Narbuko dan Abu Ahmadi, Metodologi Penelitian, (Jakarta: Bumi Aksara,

${ }^{16}$ Salim Lubis HS dan Erlies Septiana Nurbaini, op cit., hlm.16
} 
Selain data hukum sekunder, sumber data juga diperoleh dari data primer, yaitu data yang diperoleh langsung dari masyarakat yang akan di teliti. Adapun metode yang digunakan untuk mengumpulkan data ialah yaitu menggunakan studi dokumenter. Studi dokumeter merupakan studi yang mengkaji tentang berbagai dokumen, baik yang berkaitan dengan peraturan perundang-undangan maupun dokumen yang sudah ada. ${ }^{17}$

Analisis data adalah proses mencari dan menyusun secara sistematis data yang diperoleh dari hasil wawancara, catatan lapangan, dan dokumentasi, dengan cara menyusun pola, memilih mana yang penting dan harus dipelajari, membuat kesimpulan sehingga mudah dipahami diri sendiri maupun orang lain. ${ }^{18}$ Data yang telah diperoleh dari hasil penelitian ini kemudian dilanjutkan dengan analisis data secara kualitatif yaitu menganalisis data berdasarkan kualitasnya lalu di deskripsikan dengan menggunakan kata-kata sehingga diperoleh bahasan dalam bentuk kalimat sistematis dan dapat dimengerti, kemudian ditarik kesimpulan.

\section{Hasil Penelitian dan Pembahasan}

\section{Akibat Hukum Perceraian di Luar Pengadilan Menurut Undang- Undang Nomor 1 Tahun 1974}

Undang-Undang Nomor 1 Tahun 1974 Tentang Perkawinan dibuat sebagai pedoman bagi warga negara Indonesia terkait persoalan perkawinan, dan perceraian merupakan salah satunya. Khusus bagi umat Islam, pada tahun 1991 telah dikeluarkan Inpres Nomor 1 Tahun 1991 tentang Kompilasi Hukum Islam, yang isinya disamping penambahan norma hukum baru dan merupakan penegasan terhadap ketentuan peraturan perundang-undangan sebelumnya. ${ }^{19}$

Penjelasan Umum Undang-Undang Nomor 1 Tahun 1974 tentang Perkawinan, dicantumkan enam prinsip mengenai perkawinan. Keenam prinsip tersebut adalah ${ }^{20}$ :

a. Tujuan perkawinan adalah membentuk keluarga yang bahagia dan kekal;

b. Suatu perkawinan baru dinyatakan sah bilamana dilakukan menurut hukum agama dan kepercayaan masing-masing, dan dicatatkan sebagai tindakan administratif;

c. Perkawinan menganut azas monogami;

d. Untuk melangsungkan perkawinan calon mempelai harus sudah sampai usia nikah, yaitu 19 tahun bagi pria, dan 16 tahun bagi wanita;

e. Mempersukar terjadinya perceraian, dan untuk perceraian harus ada alasan tertentu dan harus dilakukan di depan sidang pengadilan;

f. Hak dan kedudukan istri adalah seimbang dengan hak dan kedudukan suami baik dalam kehidupan rumah tangga, maupun dalam pergaulan masyarakat.

\footnotetext{
${ }^{17}$ Ibid., hlm.19

${ }^{18}$ Sugiyono, Metode Penelitian Pendidikan , cet-ke-XV, (Bandung: Alfabeta, 2012),

${ }^{19}$ HM. Anshary, op cit., hlm. 75

${ }^{20}$ Ibid., hlm, 76
} hlm.329. 
Mengenai hak mutlak talak yang berada di tangan laki-laki, sebagaimana dalam ajaran hukum fikih, didalam peraturan perundang-undangan tentang perkawinan di Indonesia juga memberikan hak mutlak kepada suami untuk mentalak istrinya, tetapi dengan ketentuan ${ }^{21}$ :

a. Perceraian harus dilakukan di depan sidang pengadilan

b. Perceraian harus disertai alasan-alasan sebagaimana telah diatur undangundang;

c. Mengikuti prosedur sesuai peraturan perundang-undangan.

Hukum perkawinan di Indonesia tidak mengakui perceraian yang dilakukan di luar pengadilan. Hal ini dilakukan bertujuan untuk melindungi kaum wanita pada umumnya dan pihak istri pada khususnya. ${ }^{22}$ Selain itu pada pasal 39 Undang-Undang Nomor 1 Tahun 1974 ditegaskan bahwa : "perceraian hanya dapat dilakukan di depan sidang pengadilan setelah pengadilan yang bersangkutan berusaha dan tidak berhasil mendamaikan kedua belah pihak".

Dalam perspektif Undang-Undang Nomor 1 Tahun 1974, perceraian dilakukan oleh suami istri karena sesuatu yang dibenarkan oleh pengadilan melalui persidangan. Pengadilan mengadakan upaya perdamaian dengan memerintahkan kepada pihak yang akan bercerai untuk memikirkan segala mudaratnya jika perceraian itu dilakukan, sedangkan pihak suami dan pihak istri dapat mengadakan perdamaian secara internal, dengan musyawarah keluarga atau cara lain yang dianjurkan oleh ajaran Islam. Hanya jika perdamaian yang disarankan oleh majelis hakim di pengadilan dan pihak-pihak lain tidak memberikan solusi, sehingga rumah tangga akan lebih mudarat jika dilanjutkan, perceraian pun akan diputuskan. ${ }^{23}$

Menurut ketentuan Pasal 146 ayat (2) KHI: "suatu perceraian dianggap terjadi beserta akibat-akibatnya terhitung sejak jatuhnya putusan Pengadilan Agama yang telah mempunyai kekuatan hukum yang tetap. "24

Adapun di dalam kasus cerai talak, Pasal 131 ayat (3) KHI mengatur bahwa: "suami baru dapat mengucapkan ikrar talak terhadap istrinya di depan sidang Pengadilan Agama setelah putusan Pengadilan Agama tersebut mempunyai kekuatan hukum yang tetap". ${ }^{25}$

Dengan demikian setelah si suami mengucapkan ikrar talak terhadap istrinya, maka tidak ada halangan bekas suami tersebut untuk menikah lagi dengan perempuan lain. ${ }^{26}$

Menurut Pasal 18 Peraturan Pemerintah No. 9 Tahun 1975Tentang Pelaksanaan Undang-Undang Nomor 1 Tahun 1974 Tentang Perkawinan dan Pasal 123 Kompilasi Hukum Islam disebutkan bahwa: "perceraian baru diakui terjadi terhitung pada saat perceraian itu dinyatakan di depan sidang

${ }^{21}$ Ibid., hlm. 78

${ }^{22}$ Ibid.,

${ }^{23}$ Beni Ahmad Saebani, Op Cit., hlm. 96

${ }^{24}$ Instruksi Presiden Nomor 1 Tahun 1991 Tentang Kompilasi Hukum Islam, Pasal 146 ayat (2),

${ }^{25}$ Ibid., Pasal 131 Ayat (3)

${ }^{26}$ ibid 
pengadilan”. Selanjutnya pada Pasal 115 Kompilasi Hukum Islam juga dengan jelas disebutkan: "perceraian hanya dapat dilakukan di depan sidang Pengadilan Agama setelah Pengadilan Agama tersebut berusaha dan tidak berhasil mendamaikan kedua belah pihak." 27

Undang-Undang Nomor 1 Tahun 1974 pasal 39 menjelaskan bahwa ${ }^{28}$ :

1. Perceraian hanya dapat dilakukan di depan sidang pengadilan setelah pengadilan yang bersangkutan berusaha dan tidak berhasil mendamaikan kedua belah pihak;

2. Untuk melakukan perceraian harus ada cukup alasan, bahwa suami istri itu tidak akan dapat hidup rukun sebagai suami istri;

3. Tata cara perceraian di depan sidang pengadilan diatur dalam peraturan perundang-undangan tersendiri.

Sebagai warga negara yang hidup di negara hukum, maka mentaati ketentuan hukum adalah keharusan. Demikian juga halnya sebagai umat Islam, bahwa mengikuti kaidah agama Islam merupakan perintah Allah dan itu adalah kewajiban. Namun yang perlu dipahami ialah, bentuk ketaatan kepada Allah, bukan hanya hubungan langsung dengan Allah saja, akan tetapi juga hubungan antar sesama manusia.

Menurut ajaran agama Islam, percaya kepada Tuhan Yang Maha Esa berarti mengakui dan meyakini Kemahaesaan Allah mengatur hidup dan kehidupan alam semesta termasuk manusia didalamnya. Pengaturan itu dilakukan-Nya melalui hukum-hukumNya baik yang tertera dalam wahyu (syari'ah) maupun yang terdapat alam semesta (sunnatullah). ${ }^{29}$

Takwa kepada Tuhan Yang Maha Esa menurut ajaran Islam tidak hanya berarti takut kepada Allah, tetapi juga aktif membina dan memelihara berbagai hubungan yang ada dalam kehidupan manusia. Hubungan itu adalah hubungan manusia dengan Allah, hubungan manusia dengan dirinya sendiri, hubungan manusia dengan manusia lain dalam masyarakat, dan hubungan manusia dengan lingkungan hidupnya. Keempat tata hubungan ini harus dikembangkan secara seimbang, baik dan benar. ${ }^{30}$ Hubungan manusia dengan Allah, menurut ajaran Ketuhanan Yang Maha Esa merupakan prima causa (sebab utama) hubunganhubungan yang lain. Oleh karena itu pula pemeliharaan hubungan ini harus diutamakan oleh manusia dan dikembangkan sebaik-baiknya. Caranya adalah dengan menjalankan perintah dan menjauhi semua larangan-Nya. ${ }^{31}$

Hubungan manusia dengan dirinya sendiri dapat dipelihara antara lain dengan berlaku jujur, adil, ikhlas, berani, sabar dan pemaaf. Hubungan manusia dengan manusia lain dalam kehidupan sosial dapat dipelihara dan dikembangkan dengan antara lain, menghargai nilai dan mentaati norma yang berlaku dalam masyarakat. Hubungan manusia dengan lingkungan hidupnya, misalnya dengan memelihara dan menyayangi binatang, tumbuh-tumbuhan, tanah, air, dan udara,

\footnotetext{
${ }^{27}$ Kompilasi Hukum Islam, Pasal 115

${ }^{28}$ Beni Ahmad Saebani, Op.Cit., hlm.. 97

${ }^{29}$ Mohammad Daud Ali, Op.Cit., hlm. 25

${ }^{30}$ Mohammad Daud Ali, Op.Cit., hlm.25

${ }^{31}$ Ibid., hlm. 26
} 
serta semua isi alam semesta yang sengaja diciptakan Allah untuk kepentingan manusia dan makhluk hidup lainnya. ${ }^{32}$

Keempat hubungan takwa itu harus dilaksanakan dengan sebaik-baiknya agar tumbuh dan berkembang 'empat kesadaran tanggung jawab' dalam diri manusia. Tanggung jawab tersebut adalah tanggung jawab kepada Allah, tanggung jawab dengan hati nurani sendiri, tanggung jawab kepada manusia lain, dan tanggung jawab untuk memelihara lingkungan hidup. Keempatnya harus berkembang secara berimbang, sesuai dengan pola takwa tersebut diatas yang menempatkan tanggung jawab kepada Allah sebagai yang pertama dan terakhir dari tanggung jawab yang harus disadari dan karena itu dikembangkan oleh manusia. ${ }^{33}$

Mentaati ketentuan Allah merupakan kewajiban yang harus dilaksanakan oleh semua umat Islam. Mematuhi hukum yang nyata-nyata merupakan produk manusia, juga merupakan bagian ketaatan kepada Allah sepanjang hal yang diatur dalam hukum tersebut tidak bertentangan dengan nilai kebaikan dalam Islam.Melalui lembaga pengadilan, tampak peran negara dalam usaha menciptakan hubungan baik antara sesama manusia. Melalui pengadilan, perceraian antara suami istri berakibat sah secara hukum. Selama seorang suami belum membacakan ikrar talak di depan pengadilan, maka secara aturan negara, ia masih terikat perkawinan dengan istrinya. Sehingga jika suami melakukan perkawinan baru dengan orang lain, perkawinan tersebut dianggap tidak sah secara negara.

Oleh karena itu dapat dipahami bahwa menurut Undang-Undang Perkawinan dan Kompilasi Hukum Islam perceraian yang sah menurut hukum adalah ikrar suami yang diucapkan di depan sidang pengadilan. Perceraian yang terjadi di luar pengadilan berarti belum memutus ikatan perkawinan antara suami istri dan berakibat tidak sah secara hukum.

\section{Akibat Hukum Perceraian di Luar Pengadilan Menurut Ahli Fikih Islam}

Berbeda dengan aturan yang disebutkan dalam Undang-Undang Perkawinan, para ahli fikih mempunyai pendapat lain tentang perceraian. Beberapa ahli fikih berpendapat bahwa perceraian hukumnya sah secara agama meskipun dilakukan di luar pengadilan. Menurut pandangan Imam Mazhab, yakni Imam Syafi'i dan Imam Hanafi, tidak ada keharusan perceraian itu harus dilakukan di depan sidang pengadilan. Apabila seorang suami telah mengucap kata talak kepada istrinya, maka jatuhlah talak itu dengan syarat terpenuhi rukun talak. Dengan terpenuhinya rukun talak, maka talak dianggap sah secara agama, sehingga perceraian tidak harus dipersaksikan di depan sidang pengadilan. Sah atau tidaknya perceraian adalah jika telah terpenuhi rukun talak.

Adapun rukun talak menurut pendapat dari Imam Mazhab dan para ahli fikih adalah sebagai berikut:

\section{Mazhab Hanafi}

\footnotetext{
${ }^{32}$ Ibid.,

${ }^{33}$ Ibid., hlm. 27
} 
Menurut Mazhab Hanafi, rukun talak adalah lafal yang menjadi dilalah bagi makna talak secara bahasa yang merupakan pelepasan dan pengiriman. Melepaskan ikatan dalam makna yang terang-terangan, dan memutuskan ikatan dalam pengertian secara sindiran. Sedangkan dalam makna syar' $i$-nya adalah menghilangkan penghalalan atau isyarat yang menempati posisi lafal. ${ }^{34}$

2. Mazhab Maliki

Menurut Mazhab Maliki rukun talak ada empat, yaitu ${ }^{35}$ :

a. Mampu melakukannya;

b. Maksud, artinya maksud ucapan dengan lafal terang-terangan maupun dengan sindiran yang jelas, meskipun tidak bermaksud

c. Melepaskan ikatan perkawinan;

d. Objek, maksudnya perkawinan yang ia miliki;

e. Lafal

3. Mazhab Syafi'i Dan Mazhab Hambali

Menurut kedua Mazhab ini, rukun talak ada lima, yaitu: ${ }^{36}$

a. Laki-laki yang menalak;

b. ucapan;

c. objek;

d. kekuasaan/perwalian;

e. maksud.

4. Ibnu Juzaa

Menurut Ibnu Juzaa rukun talak ada tiga yaitu: ${ }^{37}$

a. suami yang mentalak;

b. istri yang ditalak;

c. ucapan yang berupa lafal, dan perkara yang memiliki makna yang sama.

5. Moh. Rifai

Moh. Rifai menjelaskan bahwa rukun talak ada tiga, yaitu $:^{38}$

a. Suami yang mentalak, dengan syarat baligh, berakal, dan kehendak sendiri;

b. Istri yang ditalak;

c. Ucapan yang digunakan untuk mentalak.

Imam Syafi'i menyebutkan talak juga dianggap sah bila dilakukan oleh suami yang berakal, baligh, dan atas kehendak sendiri. Maka sifat mukallaf merupakan syarat, jadi talak orang safih (pemboros), meski tidak seberapa, hukumnya tetap sah. ${ }^{39}$

Lebih lanjut Wahbah Az-Zuhaili menyatakan, talak pelaku dosa akibat mengkonsumsi sesuatu yang dapat menghilangkan kesadaran, seperti minum khamar, atau minuman keras lain adalah tetap sah. ${ }^{40}$

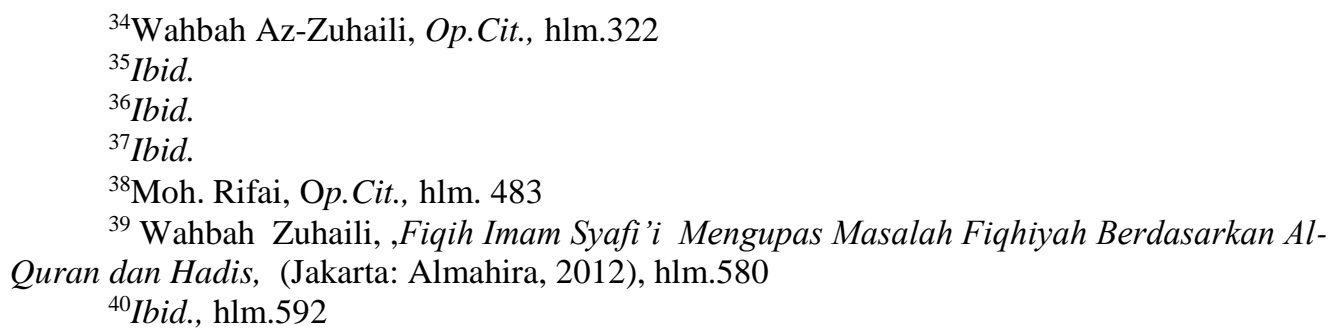


Dalam hukum Islam hak talak hanya ada pada suami. Oleh karena hak talak ada pada suami, suami harus berhati-hati dalam menyatakan kata-kata yang berakibat jatuhnya talak. Kata-kata sindiran pun dapat menyebabkan jatuhnya talak jika diucapkan dengan niat menceraikan istrinya. Menurut para ulama, sebagaimana oleh Sayyid Sabiq, dikatakan bahwa : "talak yang sah adalah talak yang diucapkan oleh suami yang baligh dan berakal. Jika suaminya gila, sedang mabuk, sehingga tidak dalam keadaan sadar, talaknya sia-sia seperti talak yang diucapkan oleh suami yang belum baligh". ${ }^{41}$

Di dalam fikih klasik, Jumhur Ulama berpendapat, bahwa hak mutlak talak ada pada suami. Oleh karena itu, kapan saja, dimana saja seorang suami ingin menjatuhkan talak terhadap istrinya, baik ada saksi atau tidak, baik ada alasan atau tidak, talak yang dijatuhkan itu hukumnya sah. ${ }^{42}$ Bahkan Jumhur Ulama mengatakan bahwa talaknya seorang suami yang dijatuhkan dalam keadaan mabukpun dihukum sah. ${ }^{43}$

\section{Macam-Macam Hukum Talak}

Berdasarkan kemaslahatan atau kemudaratannya, hukum talak ada empat ${ }^{44}$ yaitu:

1. Wajib, apabila terjadi perselisihan antara suami istri, sedangkan hakim yang mengurus perkara keduanya memandang perlu upaya keduanya bercerai.

2. Sunat, apabila suaminya tidak sanggup lagi membayar dan mencukupi kewajiban (nafkahnya), atau perempuan tidak menjaga kehormatan dirinya.

3. Haram (bid;ah) dalam dua keadaan. Pertama, menjatuhkan talak sewaktu si istri dalam keadaan haid. Kedua, menjatuhkan talak sewaktu suci yang telah dicampurinya dalam waktu suci itu.

4. Makruh, yaitu hukum asal dari talak.

Orang yang tidak sah menjatuhkan talak ada empat macam ${ }^{45}$ yaitu:

1. anak kecil

2. orang gila

3. orang yang sedang tidur

4. orang yang dipaksa.

Keterangan pertama, kedua, dan ketiga adalah sabda Rasulullah SAW: "Perbuatan tiga orang ini dipandang tidak sah yaitu orang tidur sampai dia bangun, anak kecil hingga dia baligh, orang gila hingga dia sembuh."(H.R. Abu Dawud dan Tirmidzi).

Pada zaman Jahiliyah, menurut Aisyah, banyak laki-laki yang sesuka hatinya menceraikan istrinya dengan kata-kata yang diucapkan seenaknya. Akan tetapi, istrinya masih tetap jadi istrinya kalau dirujuk diwaktu iddahnya, sekalipun sudah diceraikannya seratus kali atau lebih. Banyak suami yang dengan mudah berkata cerai dan cerai, tetapi lagi-lagi setelah itu ia meniduri istrinya. Karena banyaknya suami yang mempermainkan kata cerai, maka turunlah ayat

\footnotetext{
${ }^{41}$ Beni Ahmad Saebani, Ed., Fikih Munakahat 2, (Bandung:Pustaka Setia, 2001), hlm. 65

${ }^{42}$ Ensiklopedi Islam Jilid 5, (Jakarta: PT Ichtiar Baru Van Hoeve, 1994), hlm.55

${ }^{43}$ Ibid.

${ }^{44}$ Beni Ahmad Saebani, Op.Cit., hlm. 64

${ }^{45}$ Ibid., hlm. 95
} 
Al-Quran surah Al-Baqarah ayat 229 yang artinya ${ }^{46}$ :"Talak itu dua kali, maka jika kamu mau rujuk, peganglah dengan baik, dan jika kamu mau lepaskan, lepaskanlah dengan baik."

Dengan ayat itulah suami tidak diperbolehkan memepermainkan kata-kata talak, baik yang terang-terangan maupun dengan kata-kata sindiran, karena keduanya dapat menjatuhkan talak atau dianggap sebagai makna hakikat, dari talak. Dengan demikian, syariat Islam menetapkan talak sebagai perbuatan yang harus dihindarkan dari kehidupan suami istri. ${ }^{47}$ Ada perbedaan pendapat dari para ulama tentang sah atau tidaknya talak karena beberapa sebab. Para ulama berbeda pendapat tentang talak yang dijatuhkan karena sebab-sebab dibawah ini, yaitu: ${ }^{48}$

a. Talak karena paksaan, paksaan atau terpaksa berarti bukan dengan kehendak dan pilihannya sendiri. Orang yang terpaksa tidak bertanggung jawab atas segala tindakannya karena dia tidak mempunyai kehendak, sehingga secara objektif dipandang melakukan kemauan pemaksanya. ${ }^{49}$ Talak yang dilakukan suami karena terpaksa atau dipaksa hukumnya tidak sah, sebagaimana pendapat Imam Malik, Imam Syafi'i, Imam Ahmad, dan Imam Abu Dawud dan para fuqaha pada umumnya seperti Umar bin Khatab, Abdullah bin Umar, Ali dan Ibnu Abbas. ${ }^{50}$ Namun pendapat berbeda datang dari Abu Hanifah dan murid-muridnya. Abu Hanifah berpendapat bahwa talak karena paksaan, hukumnya sah, karena tidak ada dalil yang menyatakan talak karena paksaan tidak sah, bahkan pendapat tersebut bertentangan dengan pendapat Jumhur sahabat Nabi Muhammad SAW. Akan tetapi pendapat Imam Abu Hanifah ini bertentangan dengan hadis Nabi SAW yang berbunyi: "Umatku terbebas dari akibat hukum karena perbuatan yang keliru (khilaf), karena lupa dan bagi mereka yang dipaksa untuk berbuat sesuatu."(H.R. Ibnu Majah, Ibnu Hiban Daruquthni, Thabrani,dan Hakim).

b. Talak ketika mabuk, para fuqaha berpendapat bahwa talak ketika mabuk hukumnya sah, karena mabuknya disebabkan oleh keinginannya sendiri. Bagi suami pemabuk, apabila ia mengucapkan talak kepada istrinya, talaknya jatuh seketika dan sah sebagai talak. Ulama lainnya berpendapat bahwa talaknya tidak sah, karena orang yang mabuk sedang hilang ingatan dan kedudukannya tidak jauh berbeda dengan orang gila. Kedua orang ini sama-sama kehilangan akal, dan orang yang dipandang sebagai mukallaf harus orang yang berakal. Sebagaimana oang yang sedang mabuk lalu shalat, maka shalatnya tidak sah. ${ }^{51}$ Adapun ulama yang berpendapat bahwa talak dalam keadaan mabuk tidak sah adalah Utsman Bin Affan dan semua sahabat, Yahya bin Saad Al-Anshari, Humaid bin Abdurrahman, Rabi'ah, Laits bin Sa'ad, Abdullah bin Husain, Ishaq bin Rahawaih, Abu Tsaur, Imam Syafi'i, Imam Ahmad, pendapat Abu Ja'far Thahawi, dan Abu Hasan Al Karkhi dari Mazhab Hanafi. ${ }^{52}$ Pendapat

\footnotetext{
${ }^{46}$ Beni Ahmad Saebani, op cit., hlm. 67

${ }^{47}$ Ibid.,

${ }^{48}$ Ibid., hlm.68

${ }^{49}$ Ibid., hlm.79

${ }^{50}$ Ibid.,

${ }^{51}$ Ibid., hlm.70

${ }^{52}$ Ibid., hlm.71
} 
para ulama datas diperkuat oleh Imam Asy-Syaukani bahwa orang yang mabuk terkena sanksi ta'zir, dan jika orang yang sedang mabuk menjatuhkan talak, tentu bukan hanya talaknya tidak sah, sanksinya harus ditambah, karena ia bukan hanya telah kehilangan akalnya dengan minuman haram, bahkan ia telah merusak tali perkawinan dengan istrinya dan mencerai beraikan hubungan kasih sayang dengan keluarganya. ${ }^{53}$

c. Talak main-main,

Para fuqaha kebanyakan berpendapat bahwa talak dengan main-main dipandang sah, sebagaimana dipandang sahnya nikah dengan main-main. Ahmad, Abu Dawud, Ibnu Majah, dan Tirmidzi meriwayatkan hadis yang artinya:" "Dari Abu Hurairah bahwa Rasulullah SAW bersabda, "Tiga perkara yang kesungguhannya dipandang benar, dan main-mainnya dipandang benar pula, yaitu: nikah, talak, rujuk." Semua perbuatan tergantung pada niatnya. Jika talak dilakukan dengan main-main, tentu tidak diniatkan. Oleh karena itu talaknya tidak sah. Pendapat ini dikemukakan oleh Al-Baqir, Shadiq, dan Nashir. Niat adalah kehendak yang diniatkan oleh orang untuk dikerjakan. Hal ini memerlukan kemauan yang pasti untuk melakukan atau untuk meninggalkannya. Akan tetapi mempermainkan talak merupakan perbuatan yang buruk, karena sama dengan mempermainkan syari'at Islam, mempermainkan syari'at Islam sama dengan mempermainkan Allah dan RasulNya. Dengan demikian mempermainkan talak hukumnya haram dan dianggap dosa besar meskipun talaknya dinyatakan tidak sah oleh sebagian ulama. ${ }^{55}$

d. Talak waktu marah

Talak yang diucapkan dalam kemarahan yang mengakibatkan tidak terkontrolnya ucapan dan tidak menyadari apa yang dikatakannya, adalah tidak sah karena kemauan sehatnya hilang. Orang yang marah membabi buta, menurut Sayyid Sabiq, sama dengan orang yang tertutup akalnya, sehingga ia tidak berbeda dengan orang yang gila. Akan tetapi kemarahan yang tidak sampai menutup akal dan hatinya, seperti kemarahan yang terkendali dan karena Allah, maka talaknya sah. ${ }^{56}$ Menurut Ibnu Taimiyah, "Tertutup akal itu hakikatnya adalah seseorang yang hatinya tertutup (tidak sadar) sehingga keluar ucapan yang tidak dimaksudkannya atau tidak disadarinya, seolah-olah maksud dan kemauannya tertutup. Termasuk dalam pengertian tertutup akalnya yaitu talak karena paksaan, gila, orang yang hilang akalnya karena mabuk atau marah, semua ucapan yang tidak disengaja dan ucapan-ucapan yang tidak disadari. Jika keadaan demikian, talaknya tidak sah. ${ }^{57}$

Kemarahan menurut Sayyid Sabiq ada tiga macam, yaitu ${ }^{58}$ :

1. Marah yang menghilangkan akal, sehingga tidak sadar apa yang dikatakannya. Dalam keadaan seperti itu, tidak ada perbedaan pendapat tentang "tidak sahnya talak";

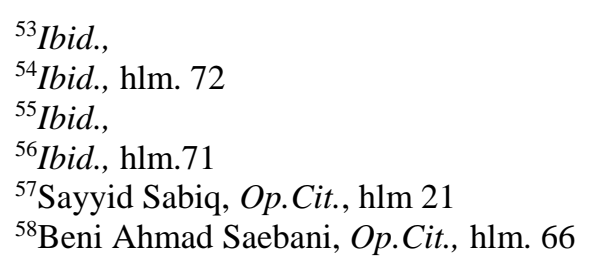


2. Marah yang tidak mengakibatkan orang kehilangan kesadaran atas apa yang dimaksud oleh ucapan-ucapannya, maka keadaan seperti ini mengakibatkan talaknya "sah";

3. Sangat marah, tetapi sama sekali tidak menghilangkan kesadaran akalnya, jika bermaksud dengan menalaknya, sah talaknya , tetapi jika tidak diniatkan atas itu, hanya sekedar main-main, para ulama menyatakan tidak sah, mekipun yang lain menyatakan sah, karena ucapan talak bukan untuk dipermainkan, karena dengan ucapan yang sekedar main-main, talaknya dapat jatuh dengan kedudukan hukum yang sah.

e. Talak ketika lupa,

Sama hukumnya dengan talak yang diucapkan karena keliru dan main-main adalah orang yang lupa, yakni tidak sah. Perbedaan antara keliru dan mainmain, yaitu bahwa talak main-main oleh agama maupun pengadilan dipandang sah, sedangkan talak karena kekeliruan ucapan hanya dipandang sah oleh pengadilan. Ini dikarenakan soal talak bukan merupakan objek main-main. ${ }^{59}$

f. Talak ketika tidak sadarkan diri.

Orang yang tidak sadarkan diri, yaitu orang yang tidak tahu lagi apa yang dikatakannya karena suatu kejadian hebat menimpanya, sehingga hilang akalnya dan berubah pikirannya. Talak orang seperti ini tidak sah, sebagaimana tidak sahnya talak orang gila, pikun, pingsan, dan orang yang rusak akalnya karena tua atau sakit atau musibah yang tiba-tiba. ${ }^{60}$

Menurut pendapat ahli fikih, seorang istri dapat dianggap tertalak apabila suaminya menjatuhkan talak kepadanya. Ketika menjatuhkan talak tersebut si suami dalam keadaan sadar, tidak dipaksa. Selain itu, pada diri suami tidak ada penghalang-penghalang jatuhnya talak seperti gila, mabuk, dan lain sebagainya. Sementara si istri dalam keadaan suci dan belum digauli, atau hamil, atau menopause. ${ }^{61}$

Dalam hal siapa yang berhak menjatuhkan talak, para ulama sepakat bahwa suami yang berakal, baligh, dan merdeka yang boleh menjatuhkan talak, dan talaknya dipandang sah. Jika suaminya gila, atau masih anak-anak, atau dalam keadaan terpaksa, talaknya dipandang sia-sia, sekalipun timbul dari keputusan dirinya. Karena talak tergolong tindakan yang mempunyai akibat dan pengaruh dalam kehidupan suami istri, mau tidak mau, pihak yang menjatuhkan talak harus sempurna kemampuannya, sehingga tindakan-tindakannya dipandang sah secara hukum. Sempurnanya kemampuan adalah adanya akal sehat, kedewasaan, dan kebebasan memilih. ${ }^{62}$

Islam tidak memerintahkan perceraian. Perceraian yang diperbolehkan sesuai dengan Al-quran dan Sunnah Nabi ketika seorang laki-laki tidak terburuburu dan memilih waktu yang tepat. Misalnya dia tidak akan menceraikan istrinya ketika istrinya sedang haid, dan ketika dia suci dari haidnya. Jika dia melakukannya, maka perceraiannya tidak sesuai dengan ajaran Nabi dan akan diharamkan. Beberapa ahli hukum sejauh ini telah sepakat bahwa perceraian itu

\footnotetext{
${ }^{59}$ Ibid., hlm.73

${ }^{60}$ Ibid., hlm.74

${ }^{61}$ Muhammad Samih Umar, Op.Cit., hlm 207

${ }^{62}$ Beni Ahmad Saebani, Op.Cit., hlm 68
} 
tidak sah karena perceraian itu tidak sesuai dengan apa yang telah Nabi perintahkan kepada kita. ${ }^{63}$

\section{Saksi Dalam Talak}

Sebagian ahli fikih mempunyai pendapat, yakni tentang perlunya saksi dalam sebuah perceraian. Di dalam kitab Al-Wasaail dari Abu Ja'far Al-Baqir, ia berkata: "talak sebagaimana diperintahkan Allah dalam Al-Quran dan seperti yang dituntunkan oleh Allah ialah seorang laki-laki memisahkan diri dari istrinya, bila telah haid lalu suci dari haidnya, maka ia hadirkan dua orang saksi laki-laki yang adil untuk menjatuhkan talaknya diwaktu perempuan itu sedang suci tanpa dikumpulinya." 64

Ibnu Katsir meriwayatkan dalam kitab tafsirnya dari Ibnu Juraij bahwa Atha' pernah berkata tentang firman Allah Surah At-Thalaq ayat (2): "dan persaksikanlah kepada dua orang laki-laki yang adil diantara kamu." Disini Allah memerintahkan menghadirkan saksi. Para sahabat menyatakan bahwa talak harus disaksikan agar kedudukannya lebih kuat.Pendapat yang sama juga dinyatakan oleh Ash-Suyuthi. Ia mengemukakan pendapat Abdur Razaq dan Abd bin Humaid yang diterima dari Atha, yang berkata": "Nikah itu dengan saksi, talak dengan saksi, dan rujuk dengan saksi." 65

Dalam hal jika ada perselisihan yang ditakutkan dapat membahayakan jiwa suami atau istri kiranya terlebih dahulu mengutus seorang sebagai penengah yang berusaha untuk mendamaikan keduanya. Hal ini sebagaimana firman Allah QS.An-Nisa' ayat (35), yang berbunyi:"Dan jika kamu khawatirkan ada persengketaan antara keduanya, maka kirimlah seorang hakam dari keluarga laki-laki dan seorang hakam dari keluarga perempuan. Jika kedua orang hakam itu bermaksud mengadakan perbaikan, niscaya Allah memberi taufik kepada suami istri itu. Sesungguhnya Allah Maha Mengetahui lagi Maha Mengenal”. QS.An-Nisa' ayat (35).

Al-Quran dalam banyak kesempatan selalu menyarankan agar suami istri selalu bergaul secara makruf dan jangan menceraikan istrinya dengan sebab-sebab yang tidak prinsipil. Jika terjadi pertengkaran yang sangat memuncak diantara suami istri dianjurkan bersabar dan berlaku baik untuk tetap rukun dalam rumah tangga, tidak langsung membubarkan perkawinan mereka, tetapi hendaklah menempuh usaha perdamaian terlebih dahulu dengan mengirim seorang hakam dari keluarga pihak suami dan seorang hakam dari pihak istri untuk mengadakan perdamaian. Jika usaha ini tidak berhasil dilaksanakan, maka perceraian baru dapat dilaksanakan. ${ }^{66}$

Sebagian para ahli fikih justru berpendapat berbeda. Menurut mereka bahwa talak tetap sah meski tanpa saksi. Menurut Sayyid Sabiq, para fuqaha berpendapat bahwa talak sah tanpa dipersaksikan di hadapan orang lain. Sebab talak termasuk hak suami dan tidak memerlukan bukti untuk menggunakan hak ini. Tidak ada keterangan dari Nabi maupun para sahabatnya yang menunjukkan adanya

\footnotetext{
${ }^{63}$ Yusuf Qaradhawi, Fiqih Wanita, (Bandung: Jabal, 2006), hlm.87

${ }^{64}$ Beni Ahmad Saebani, Op Cit., hlm.85

${ }^{65}$ Ibid., hlm. 85

${ }^{66}$ Abdul Manan, Op Cit., hlm.449
} 
keperluan saksi dalam menjatuhkan talak. Pendapat Sayyid Sabiq tersebut, menegaskan tiga hal mendasar, yaitu ${ }^{67}$ :

1. talak merupakan hak suami

2. talak tidak membutuhkan saksi

3. tidak ada dalil yang pasti tentang keharusan talak disaksikan.

Seruan menjadikan talak berada ditangan qadhi (hakim) tidak memiliki faidah karena hal ini bertabrakan dengan ketetapan syariat. Hal ini disebabkan laki-laki memiliki keyakinan secara agama bahwa ini adalah haknya. Jika talak dijatuhkan, terjadi pengharaman tanpa menunggu keputusan qadhi. ${ }^{68}$

Hal itu juga merupakan maslahat si perempuan itu sendiri karena talak bisa saja terjadi akibat berbagai sebab yang bersifat rahasia yang tidak baik jika disebarkan. Jika talak berada di tangan qadhi, maka terbongkar rahasia kehidupan suami istri dengan tersebarnya hukum, dan direkamnya berbagai sebabnya dalam catatan pengadilan. Bisa jadi sulit untuk menetapkan sebab karena ketidaksukaan yang bersifat alami, dan berbedanya akhlak antara suami istri. ${ }^{69}$

Adanya hak mutlak talak ditangan lelaki, seolah memberi peluang bagi para lelaki untuk berlaku semena-mena kepada perempuan. Sebab dengan adanya hak talak ditangan mereka, mereka sangat mudah menyebut kata 'talak' kepada istrinya, tanpa memikirkan dengan matang akibat yang akan terjadi.

Menurut fikih Islam hak mutlak talak berada ditangan laki-laki. Hal ini bukan tanpa alasan. Talak dijadikan ditangan laki-laki bukan ditangan perempuan meskipun dia adalah pasangan dalam akad untuk menjaga perkawinan, serta untuk menilai berbagai bahaya pengakhiran perkawinan dengan cara yang cepat dan tidak terkontrol. Hal itu karena laki-laki yang membayar mahar dan yang memberikan nafkah kepada istri dan rumah biasanya lebih memperhatikan konsekuensi berbagai perkara, dan lebih jauh dari sikap kesembronoan dalam tindakan yang bisa memberikan keburukan yang besar baginya. ${ }^{70}$

Islam memberikan hak talak hanya kepada laki-laki, karena ia yang lebih bersikeras untuk melanggengkan tali perkawinannya yang telah dibiayainya dengan hartanya begitu besar. Sehingga kalau ia mau bercerai atau kawin lagi, ia perlu membiayainya lagi dalam jumlah yang sama atau lebih banyak lagi. ${ }^{71}$

Berdasarkan pembahasan diatas, maka menurut pendapat ahli fikih Islam, melakukan perceraian di luar pengadilan adalah boleh dan akibat hukumnya sah secara agama. Perceraian atau talak dianggap sah sepanjang telah memenuhi rukun talak dan tidak bertentangan dengan syarat-syarat

\section{Proses Penegakan Hukum Terhadap Pereraian di Luar Pengadilan}

Dalam penerapannya, hukum memerlukan suatu kekuasaan untuk mendukungnya. Ciri utama inilah yang membedakan antara hukum disatu pihak dengan norma-norma sosial lainnya dan norma agama. Kekuasaan itu diperlukan oleh karena hukum bersifat memaksa. Tanpa adanya kekuasaan, pelaksanaan

\footnotetext{
${ }^{67}$ Ibid., hlm. 83

${ }^{68}$ Yusuf Qaradhawi, Op.Cit., hlm. 322

${ }^{69}$ Ibid.,

${ }^{70}$ Ibid.,

${ }^{71}$ Beni Ahmad Saebani, Op.Cit., hlm.67
} 
hukum dimasyarakat akan mengalami hambatan. Semakin tertib dan teratur suatu masyarakat, makin berkurang diperlukan dukungan kekuasaan. ${ }^{72}$

Hukum merupakan salah satu sumber dari kekuasaan, disamping sumbersumber lainnya seperti kekuatan dan kewibawaan. Selain itu, hukum pun merupakan pembatas bagi kekuasaan, oleh karena kekuasan itu mempunyai sifat yang buruk, yaitu selalu merangsang pemegangnya untuk ingin memiliki kekuasaan yang melebihi apa yang dimilikinya. ${ }^{73}$

Baik buruknya suatu kekuasaan, bergantung dari bagaimana kekuasan tersebut dipergunakan. Artinya, baik buruk kekuasaan senantiasa harus diukur dengan kegunaannya untuk mencapai suatu tujuan yang sudah ditentukan atau disadari oleh masyarakat lebih dahulu. ${ }^{74}$

Persoalan perceraian merupakan persoalan antar individu satu dengan indvidu lainnya. Untuk menyelesaikan persoalan tersebut, diperlukan sebuah mekanisme yang baik yang tersusun dalam sebuah aturan yang mempunyai daya paksa agar ada kepastian hukum antar individu yang berkonflik.

Dari sudut pandang bernegara, dalam pandangan Islam suatu komunitas Islam dimanapun berada, akan menghadapi paling tidak tiga kategori hukum ${ }^{75}$ yaitu: hukum syari'ah, hukum fikih, dan siyasah as-syari'ah. Syari'ah sebagai Kitab Allah terdiri dari norma-norma yang wajib dilaksanakan, baik dalam bentuknya sebagai ibadah, maupun sebagai pranata sosial, yang terdiri dari norma, moral, norma etika, dan norma hukum. Allah mewajibkan kepada umat Muslim untuk menjalankan syari'ah itu dalam kehidupan individual maupun bermasyarakat dan bernegara dengan penuh keyakinan dan kesadaran. ${ }^{76}$

Hukum Islam sebagai satu pranata sosial memiliki dua fungsi, pertama sebagai kontrol sosial dan kedua sebagai nilai baru dan proses perubahan sosial. Jika yang pertama, hukum Islam ditempatkan sebagai Blue Print atau cetak biru Tuhan yang selain sebagai kontrol sosial juga sekaligus sebagai social engineering terhadap keberadaan suatu komunitas masyarakat. ${ }^{77}$

Sementara yang kedua, hukum lebih merupakan produk sejarah yang dalam batas-batas tertentu diletakkan sebagai justifikasi terhadap tuntutan perubahan sosial, budaya dan politik. Oleh karena itu dalam konteks ini Hukum Islam dituntut akomodatif terhadap persoalan umat tanpa kehilangan prinsipprinsip dasarnya. ${ }^{78}$ Kembali kepada konsep "tujuan dari hukum Islam" itu sendiri, kita mengacu pada tujuan umum bahwa hukum Islam berusaha untuk memenuhi kebutuhan yang berkenaan dengan kehidupan manusia serta tujuan spesifik tertentu, perintah hukum tersebut diterapkan dalam rangka untuk mencapai tujuan tersebut. $^{79}$

\footnotetext{
${ }^{72}$ Lili Rasjidi dan Ira Thania Rasjidi, Op.Cit.,hlm. 75

${ }^{73}$ Ibid., hlm.76

${ }^{74}$ Ibid.,

${ }^{75}$ Abdussalam, Mimbar Hukum Nomor 64 Tahun 2004, hlm. 6 sebagaimana yang dikutip oleh Hukum Perkawinan di Indonesia, hlm.2

${ }^{76} \mathrm{HM}$ Anshary, Op.Cit., hlm.3

${ }^{77}$ Ahmad Rofiq, Op.Cit., hlm.98

${ }^{78}$ Ibid., hlm .99

${ }^{79}$ Muhammad Syukri Albani Nasution, Op.Cit. hlm. 179
} 
Sedangkan sasaran hukum Islam dapat digolongkan kedalam dua kategori, yaitu spesifik dan umum. Sasaran umum hukum Islam mengarahkan kepada kesejahteraan manusia pada umumnya. Tujuannya adalah mereka yang memiliki tujuan mewujudkan kesejahteraan umum manusia, baik didunia maupun diakhirat. ${ }^{80}$ Sedangkan sasaran spesifik hukum Islam yaitu merealisir aktivitas manusia lebih dangkal, seperti ekonomi, kehidupan berkeluarga, dan politik. Tujuan spesifik hukum Islam adalah hukum Islam yang berusaha untuk mewujudkan dalam ranah sempit aktivitas manusia, seperti ekonomi, kehidupan keluarga, atau tatanan politik. ${ }^{81}$

Suatu garis hukum yang terdapat di dalam Al-Quran dan hadis Nabi yang telah berhasil diwujudkan dalam bentuk undang-undang atau peraturan perundang-undangan, dan secara yuridis keberadaannya bersifat memaksa. Ketentuan-ketentuannya wajib ditaati dan dijalankan oleh setiap orang. Disinilah baru berlaku asas legalitas yang secara yuridis menjamin suatu kepastian hukum terhadap suatu perbuatan hukum atau suatu peristiwa hukum, dan memberikan sanksi dan hukuman bagi orang yang tidak mentaati suatu ketentuan hukum. ${ }^{82}$

Dalam hal penetapan kebijakan hukum di Indonesia pemerintah telah menjadikan hukum Islam sebagai bagian dari hukum Nasional. Dalam rangka pembangunan sistem hukum nasional, pemerintah menetapkan kebijaksanaan untuk memanfaatkan tiga sistem yang eksis (living law) di Indonesia, yaitu sistem hukum adat, Islam dan Barat (Belanda) sebagai bahan bakunya. ${ }^{83}$

Tatanan hukum nasional Indonesia harus mengandung ciri $^{84}$ :

1. Berwawasan kebangsaan dan berwawasan nusantara

2. Mampu mengakomodasi kesadaran hukum kelompok etnis kedaerahan dan keyakinan agama

3. Sejauh mungkin berbentuk tertulis dan terunifikasi

4. Bersifat rasional yang mencakup rasionalitas efisiensi, rasionalitas kewajaran, rasionalitas kaidah dan nilai.

5. Responsif terhadap perkembangan aspirasi dan ekspektasi masyarakat.

Jika di tilik lebih dalam, sebenarnya undang-undang perkawinan turut mengambil konsep-konsep Hukum Islam dalam pengaturannya. Artinya nilai-nilai Islam tidak dikesampingkan dalam penyusunan undang-undang ini. hanya saja perlu beberapa penekanan lebih detail terhadap pendapat ahli fikih agar lebih cocok untuk diterapkan pada saat ini.

Epistimologi hukum Islam sangat menentang asumsi-asumsi yang muncul terhadap sebuah persoalan tanpa melalui proses konfirmasi yang mendalam. Selain itu epistimologi hukum Islam Indonesia menempatkan hukum negara sebagai bagian yang tidak terpisahkan dari proses penciptaan kemaslahatan, bukan kemudian menghadapkannya dengan hukum Islam yang notabene masih dalam kitab-kitab fikih tersebut. ${ }^{85}$

\footnotetext{
${ }^{80}$ Ibid.,

${ }^{81}$ Ibid.,

${ }^{82}$ H.M. Anshary, Op.Cit., hlm. 4

${ }^{83}$ Muhammad Syukri Albani Nasution, Op.Cit., hlm. 167

${ }^{84}$ Ibid., hlm. 168

${ }^{85}$ Muhammad Syukri Albani Nasution, Op.Cit., hlm.171
} 
Penegakan hukum tidak hanya persoalan sanksi, namun juga tentang bagaimana negara bisa melahirkan sebuah aturan yang didalamnya ada keseimbangan antara hukum Islam sebagai salah satu hukum yang hidup dalam masyarakat dengan hukum positif dalam hal ini undang-undang perkawinan. Oleh sebab itulah perlu adanya sebuah peraturan yang dibuat oleh pemerintah untuk menciptakan keseimbangan sehingga suatu hukum bisa ditaati secara menyeluruh oleh setiap warga negara.

Undang-undang perkawinan sendiri tidak mengatur tentang pemberian sanksi bagi pelaku perceraian di luar pengadilan. Sebab masalah perceraian bukanlah sebuah tindak kejahatan seperti pidana pada umumnya, yang mengharuskan ada sanksi ketika melanggarnya. Sama halnya dengan undangundang perkawinan, dalam hukum Islam juga tidak diatur tentang pemberian sanksi bagi pelaku perceraian di luar pengadilan. Hal ini jelas, dikarenakan bahwa dalam ketentuan fikih, dimanapun di ucapkan kata talak, maka hal tersebut dipandang sah secara agama, kecuali jika rukun talak ada yang tidak terpenuhi, sebagaimana yang telah dijelaskan di atas.

Sejak awal hukum Islam sebenarnya tidak memiliki tujuan lain kecuali kemaslahatan (keadilan) manusia. Ungkapan bahwa hukum Islam dicanangkan demi kebahagiaan manusia lahir batin dan duniawi ukhrawi, sepenuhnya mencerminkan kemaslahatan manusia. ${ }^{86}$ namun negara tidak mungkin dapat memberlakukan hukum Islam semata dalam persoalan ini, sebab seperti diketahui, Indonesia merupakan negara pancasila dengan keanekaragaman yang ada didalamnya. Sehingga hukum yang bisa diterapkan adalah hukum yang mampu diterima oleh semua rakyatnya dengan tetap memperhatikan nilai-nilai agama, dan sosial budaya.

Pada dasarnya masalah perceraian termasuk ranah hukum privat, berbeda dengan hukum pidana, yang hubungannya antara individu dengan negara. Akan tetapi peran negara untuk membuat sebuah peraturan perundang-undangan yang bisa menciptakan keteraturan dan keadilan dalam masyarakat tetap di perlukan. Negara kiranya dapat menjadi 'mediator' dalam hal terjadi perselisihan yang terjadi pada masyarakat. Agar dalam pelaksanaan perundang-undangan yang bertujuan untuk pembaharuan itu dapat berjalan sebagaimana mestinya, hendaknya perundang-undangan yang dibentuk itu sesuai dengan apa yang menjadi inti pemikiran aliran Sociological Jurisprudende, yaitu hukum yang baik hendaknya sesuai dengan hukum yang hidup dalam masyarakat. ${ }^{87}$

Kaitan yang erat antara hukum dan nilai-nilai sosial budaya masyarakat itu ternyata bahwa hukum yang baik tidak lain adalah hukum yang mencerminkan nilai-nilai yang hidup dalam masyarakat. ${ }^{88}$ Suatu hal yang harus diakui bahwa bidang perkawinan dalam hukum Islam memiliki kompleksitas masalah yang tidak sederhana. Oleh karena itu penanganan dan penyelesaian sengketa, khususnya perceraian tidak boleh tidak, harus melibatkan kebijakan pemerintah/negara. Hal ini karena rumah tangga merupakan unit terkecil suatu

\footnotetext{
${ }^{86}$ Ibid., hlm. 177

${ }^{87}$ Lili Rasjidi, Op.Cit., hlm 79

${ }^{88}$ Mochtar Kusumatamadja, Fungsi dan Perkembangan Hukum dalam Pembangunan Nasional, (Jakarta: Bina Cipta), hlm.8
} 
negara. Jika rumah tangga di suatu negara itu teratur, harmonis, bermoral, terprogram dan tertata rapi, maka akan nampak dalam kehidupan berbangsa dan bernegara. Karena itu keterlibatan pemerintah/negara merupakan suatu keharusan. ${ }^{89}$

Melakukan perceraian di luar pengadilan memang bukanlah sebuah kejahatan. Sebab hingga saat ini tidak ada satu aturanpun yang menyatakan bahwa perbuatan tersebut dapat dihukum. Akibatnya sering terjadi kesewenangwenangan dari satu pihak yang pada akhirnya bisa merugikan pihak lainnya, bahkan bisa juga merugikan keduanya. Hal ini selain bertentangan dengan nilai dan norma dalam masyarakat, juga bertentangan dengan nilai yang terkandung dalam ajaran Islam. Mendapati kenyataan tersebut, negara diharapkan dapat berperan serta dalam upaya memberikan keadilan serta kepastian hukum dengan membuat sebuah regulasi yang didalamnya memuat ketentuan yang tidak berbenturan satu sama lain.

Dalam ajaran Islam, secara tekstual memang tidak ada keharusan memberlakukan hukum melalui legislasi. Namun menurut kaidah Ushul Fiqih: "sesuatu yang mubah itu bisa menjadi wajib, jika manfaat yang diberikan oleh sesuatu itu lebih besar untuk memberikan jalan utama bagi terlaksananya sesuatu yang diperintahkan". Atas dasar itu, jika untuk efektivitas hukum Islam di Indonesia diperlukan campur tangan pemerintah, maka legislasi merupakan kebutuhan yang urgen. ${ }^{90}$

Fikih merupakan hukum-hukum syar'i yang bersifat teknis praktis yang dikaji dan digali dari sumbernya yang asli berupa hukum dasar yaitu Al-Quran dan Hadis Nabi. Untuk mengaplikasikannya dalam kehidupan umat manusia, diperlukan suatu lembaga yang disebut siyasah syar'iyah. Siyasah syar'iyah didefinisikan sebagai kewenangan pemerintah untuk melakukan kebijakan yang menghendaki kemaslahatan melalui aturan yang tidak bertentangan dengan agama.

Hukum bukan hanya memperhatikan subjeknya, tetapi sekaligus objeknya. Subjek hukum harus memenuhi syarat-syarat fisik psikalnya, sedangkan objeknya tidak mutlak demikian. Komponen yang menguatkan hukum dan mengabadikan hukum sebagai panglima bagi tegaknya keadilan dan persamaan hak serta kewajiban adalah ${ }^{91}$ :

a. Adanya hukum berupa ajaran yang bersumber dari agama yang dianut oleh masyarakat,

b. Adanya hukum yang berbentuk norma sosial yang diyakini kebenarannya oleh masyarakat lokalnya.

Berdasarkan penjelasan diatas, maka penerapan sanksi dalam proses penegakan hukum terkait perceraian di luar pengadilan tidak bisa dilakukan. Hal ini tidak sesuai dengan asas legalitas dalam hukum pidana, dimana tidak ada satu perbuatan yang dapat dihukum sebelum ada undang-undang yang mengaturnya. Artinya pendapat ahli Fikih terkait perceraian di luar pengadilan, meski

\footnotetext{
${ }^{89}$ Ibid., hlm.75

${ }^{90}$ Muhammad Daud Ali, Op.Cit., hlm. 170

${ }^{91}$ Muhammad Syukri Albani Nasution, Op.Cit., hlm. 81
} 
merupakan hasil ijtihad para ulama, namun merupakan bagian dari hukum Islam, yang tetap bisa dipedomani dan diikuti oleh umat Islam.

Peran serta negara dalam proses penegakan hukum, terlihat dari lahirnya lembaga-lembaga untuk menyelesaikan setiap permasalahan dalam keluarga yang didalamnya terdapat aturan hukum demi mencipakan tujuan negara yang sejalan pula dengan tujuan hukum Islam. Sebagai contoh, adanya Kantor Urusan Agama (KUA) serta lembaga-lembaga zakat yang semuanya menegaskan turut andilnya negara dalam pelaksnaan hukum Islam di Indonesia.

Sejalan dengan tujuan Syariat Islam, maka pencapaian yang dikehendaki adalah terciptanya ketertiban dan kepastian yang menuju pada keadilan bagi umat Islam. Segala sesuatu yang dilakukan di muka bumi ini tidak lain untuk tercapainya keadilan. ${ }^{92}$ Negara indonesia mengakui keberadaan hukum Islam sebagai bagian hukum yang hidup dalam masyarakat, oleh karenanya, dalam penerapan hukum harus memperhatikan nilai-nilai yang terkandung dalam agama Islam.

\section{Kesimpulan}

1. Perceraian di luar pengadilan menurut Undang-Undang No.1 Tahun 1974 Tentang perkawinan berakibat tidak sah secara hukum, sebab tidak dapat memberi kepastian hukum terhadap mantan istri dan anak-anak. Perceraian yang diakui oleh negara adalah perceraian yang dilakukan di depan sidang pengadilan dengan alasan-alasan yang sesuai dengan perundang-undangan yang berlaku. Sebab perceraian yang dicatatkan negara, selain bertujuan agar tercipta tertib administratif, juga untuk memberikan keadilan serta perlindungan hukum bagi kedua belah pihak. Perceraian menurut pendapat ahli fikih tidak mensyaratkan harus dilakukan di depan pengadilan, sebab perceraian yang terjadi di luar pengadilan, tetap dipandang sah secara agama Islam. Sahnya suatu perceraian menurut pendapat ahli fikih ialah jika terpenuhinya rukun talak. Syariat dan fikih berbeda. Ketentuan hukum syariat tidak bisa berubah sebab ketentuannya berasal Allah, sedangkan fikih merupakan hasil pemikiran manusia, yang dapat berubah sepanjang tidak bertentangan hukum-hukum Syariat. Sedangkan pendapat ahli fikih merupakan hasil pemikiran para fuqaha yang dapat berubah sesuai dengan perkembangan zaman. Hukum fikih boleh dinterpretasikan secara bebas oleh ahli fikih sejauh tidak bertentangan dengan Syari'at.

2. Penegakan hukum oleh negara tidak hanya menyangkut pemberian sanksi, akan tetapi juga sumbangsih atau peran serta negara dalamdengan dibentuknya lembaga-lembaga yang terkait dengan masalah hukum keluarga, misalnya Kantor Urusan Agama, lembaga zakat, dan sebagainya. Kesemuanya demi tercapainya tujuan negara yaitu keteraturan, kepastian dan keadilan, yang pada akhirnya bermuara juga pada satu tujuan hukum Islam yaitu tercapainya kemaslahatan umat. Negara belum bisa memberikan sanksi bagi pelaku perceraian di luar pengadilan, sebab tidak ada ketentuan dalam peraturan perundang-undangan yang menjelaskan bahwa melakukan

\footnotetext{
${ }^{92}$ Iman Jauhari, Op.Cit., hlm.23
} 
perceraian di luar pengadilan merupakan kejahatan yang bisa dihukum, sebagaimana asas legalitas dalam hukum pidana bahwa tidak ada perbuatan yang bisa dihukum sebelum ada ketentuan yang mengaturnya.

\section{DAFTAR PUSTAKA}

\section{A. Buku}

Alperdorn, L.J. Van, Pengantar Ilmu Hukum, Cetakan ke 29, Jakarta: Pradnya Paramita, 2018

Anshary, HM. Hukum Perkawinan di Indonesia, Yogyakarta: Pustaka Pelajar, 2010.

Az-Zuhaili, Wahbah, Fiqih Imam Syafi'i Mengupas Masalah Fiqhiyah Berdasarkan Al-Quran dan Hadist Jakarta: Almahira, 2012

------ Fiqih Islam Wa Adillatuhu, Jakarta: Gema Insani, 2011

Dellyana, Shanty, Konsep Penegakan Hukum, Yogyakarta: Liberty, 1988

Djazuli, Ahmad, Ilmu Fiqh: Sebuah Pengantar, Bandung: Orba Sakti, 1991

Efendi, Satria. Problematika Hukum Keluarga Islam Kontemporer Analisis Yurisprudensi Dengan Pendekatan Ushuliyah, Jakarta: Kencana, 2004

Harahap, M.Yahya. Kedudukan, Kewenangan dan Acara Peradilan Agama, Jakarta: Sinar Grafika, 2005.

Jauhari, Iman, Kapita Selekta Hukum Islam, Medan: Pustaka Bangsa Press, 2007

------ Buku Ajar Hukum Islam, Medan: Perdana Publishing, 2012

Ka'bah, Rifyal, Hukum Islam di Indonesia, Jakarta: Universitas Yarsi, 1999

Kusumatamadja, Mochtar, Fungsi dan Perkembangan Hukum Dalam Pembangunan Nasional,Jakarta: Bina Cipta

L Tanya, Bernard, Yoan N. Simanjuntak, Markus Y. Hage, Teori Hukum Strategi Tertib Manusia Lintas Ruang dan Generasi, cet. III, Yogyakarta: Genta Publishing, 2010

Lubis, Salim HS dan Erlies Septiana Nurbaini, Penerapan Teori Hukum Pada Penelitian Tesis Dan Disertasi, Jakarta: Raja Grafindo Persada, 2014

M. Jakfar, Tamizi, Poligami dan Talak Liar Dalam Perspektif Hakim Agama di Indonesia, Banda Aceh: Ar-Raniry Press, 2007.

Madjid, Nurcholish. Islam Doktrin dan Peradaban, Cet 1, Jakarta: Yayasan Wakaf Paramadina, 1992

Manan, Abdul, Penerapan Hukum Acara Perdata di Lingkungan Peradilan Agama, Jakarta: Kencana Media Group, 2005.

------- Reformasi Hukum Islam di Indonesia, Jakarta: PT.Raja Grafindo Persada, 2006.

Mazkur, Muhamad Salam, al-Qada' fi al-Islam, Alih bahasa Imron AM, Surabaya: Bina Ilmu, 1990

Mertokusumo,Sudikno, Bab-Bab Tentang Penemuan Hukum, Yogyakarta: Citra Aditya Bakti, 1993

Narbuko, Cholid dan Abu Ahmadi, Metodologi Penelitian, Jakarta: Bumi Aksara, 2013 
Nasution, Muhammad Syukri Albani, Filsafat Hukum Islam, Jakarta: Rajawali Press, 2014

Poernomo, Bambang, Asas-asas Hukum Pidana, Jakarta: Ghalia Indonesia, 1998

Qaradhawi, Yusuf, Fiqih Wanita Segala Hal Mengenai Wanita, Surabaya: Jabal, 2006

Rahardjo, Satjipto, Masalah Penegakan Hukum, Bandung: Sinar Baru

Rasjidi, Lili dan IraThania Rasjidi, Dasar-Dasar Filsafat Dan Teori Hukum, Bandung: PT. Citra Aditya Bakti, 2010

Rifai, Mohd. Ilmu Fiqh Islam Lengkap, Semarang : CV.Toha Putra, 1978

Sabiq, Sayyid, Fiqh Al Sunnah, Bandung: PT. Al Ma'arif, 1994

------ Fiqh Sunnah juz II, Kairo : Jumhuriyah Mesir Al-Arabiyah, 1999

Saebani Beni Ahmad. Fiqh Munakahat Jilid 1, Bandung: Pustaka Setia, 2001

Fiqh Munakahat Jilid 2, Bandung: Pustaka Setia, 2001

Simanjuntak, P.N.H., Pokok-Pokok Hukum Perdata Indonesia, Jakarta: Pustaka Djambatan, 2007

Singarimbun, Masri dan Sofian Effendi, Metode Penelitian Survey, Jakarta: LP3ES

Soekamto, Soerjono, Pengantar Sosiologi Hukum, Jakarta: Bhratara Karya Aksara, 1977

------ Teori Sosiologi Tentang Pribadi Dan Masyarakat, Jakarta: Ghalia Indonesia, 1998

Faktor-Faktor Yang Mempengaruhi Penegakan Hukum, Jakarta: PT.Raja Grafindo Persada, 2012

Soekanto, Soerjono dan Sri Mamudji, Penelitian Hukum Normatif Suatu Tinjauan Singkat, Jakarta: Raja Grafindo Persada, 2010

Subagio dan SlametSupriatna, Dasar-Dasar Ilmu Hukum, Jakarta: Alumni Pressindo.

Subekti, Pokok-Pokok Hukum Perdata, Jakarta: PT. Intermasa, 2001.

Sugiyono, Metode Penelitian Pendidikan, cet-ke-XV, Bandung : Alfabeta, 2012

Sumarso, Siswantoro, Penegakan Hukum Psikotropika, Jakarta: PT.Raja Grafindo Persada, 2004

Syafi'i, Rachmat, Ilmu Ushul Figh, Bandung: Pustaka Setia, 1991

Syaltut, Mahmud, al-Islam 'Aqidah wa Syari'ah, Kairo: Dar al-Qalam, 1966

Syarifuddin, Amir, Pembaharuan Pemikiran Dalam Hukum Islam, Padang: Angkasa Raya, 1993

------ Hukum Perkawinan Islam di Indonesia, Jakarta: Prenada Media, 2007

Wahab Khallaf, Abdul, Sejarah Pembentukan dan Pengembangan Hukum Islam, Jakarta:PT. Raja Grafindo Persada, 2001

Ziauddin, Sardan Penelitian Kuantitatif dan Kualitatif, Bandung: Mizan, 1996.

B. ARTIKEL

Rahardjo,Satjipto, “Indonesia Butuhkan Penegakan Hukum Progresif” Kompas (15 Juni 2002) 


\section{MAKALAH}

Rahardjo, Satjipto, "Hukum Progresif (Penjelajahan Suatu Gagasan)”, Makalah disampaikan pada acara Jumpa Alumni Program Doktor Ilmu Hukum Undip Semarang, tanggal 4 September 2004

\section{PERATURAN PERUNDANG-UNDANGAN}

Indonesia, Undang-Undang Dasar 1945

Indonesia, Undang-Undang Peradilan Agama, UU Nomor 50 Tahun 2009

Indonesia, Undang-Undang Perkawinan, UU Nomor 1 Tahun 1974

Instruksi Presiden Nomor 1 Tahun 1991 tentang Kompilasi Hukum Islam

\section{E. KAMUS}

Kamus Besar Bahasa Indonesia Kamus Besar Bahasa Indonesia,Jakarta: Balai Pustaka, 2001, hlm.517

Ensiklopedi Islam

\section{F. INTERNET}

Pramesti ,Tri Jata Ayu, "Apa Perbedaan Peradilan dan Pengadilan?" http://m.hukumonline.com/klinik/detail/ulasan/perbedaan-peradilan-denganpengadilan/ Diunduh 18 Januari 2019 